Article

\title{
Profiles of Violence and Alcohol and Tobacco Use in Relation to Impulsivity: Sustainable Consumption in Adolescents
}

\author{
María del Carmen Pérez-Fuentes ${ }^{1, *} \mathbb{C}^{\text {, }}$, María del Mar Molero Jurado ${ }^{1}(\mathbb{D}$, \\ Ana Belén Barragán Martín ${ }^{1}$ and José Jesús Gázquez Linares ${ }^{1,2}$ \\ 1 Department of Psychology, Faculty of Psychology, University of Almería, 04120 Almería, Spain; \\ mmj130@ual.es (M.d.M.M.J.); abm410@ual.es (A.B.B.M.); jlinares@ual.es (J.J.G.L.) \\ 2 Department of Psychology, Faculty of Psychology, Universidad Autónoma de Chile, 4780000 Santiago, Chile \\ * Correspondence: mpf421@ual.es; Tel.: +34-950015598
}

Received: 31 December 2018; Accepted: 24 January 2019; Published: 26 January 2019

\begin{abstract}
The purpose of this study was to identify different adolescent profiles identified by their tobacco and alcohol use and patterns of violent behavior, as well as to analyze the extent to which such adolescents show impulsivity traits. The participants were selected by cluster random sampling. There were a total of 822 high school students in the sample, aged 13 to 18 years with a mean age of $14.84(S D=0.87)$. A cluster analysis with the following variables was conducted to form the groups: use of tobacco, use of alcohol, physical aggression, verbal aggression, anger, and hostility. A total of three groups of adolescents resulted from these six variables. A multivariate comparison demonstrated the existence of significant between-group differences, and an individual analysis of each of the dependent variables (impulsivity dimensions) showed that the relationship was statistically significant in all cases. In conclusion, the analysis of factors possibly associated with risk behavior in adolescents creates the possibility for and guides intervention in different stages of development in order to encourage sustainable consumption in adolescents.
\end{abstract}

Keywords: tobacco; alcohol; physical aggression; verbal aggression; impulsivity

\section{Introduction}

Adolescence is a period of transition into adult life in which a diversity of changes and stressful experiences combine [1] that could lead to involvement in situations that severely compromise development [2]. Thus, issues such as substance use [3,4] or peer relations could develop into problematic behavioral patterns in adolescents.

In Spain, the Survey on the Use of Drugs by High School Students 2014/2015 and the Survey on Alcohol and Drugs in Spain (EDADES) 2017/2018 [5,6] found a considerable improvement in the reduction of use habits as compared to previous versions of the surveys. Although this report contains data on a wide variety of substances, special attention is given alcohol and tobacco, which have a wider adolescent use pattern.

In recent years, the use of these substances, which are relatively accessible to young people, and their relationship with interpersonal violence have become a public health problem. The specific relationship between youth violence and substance use has been widely documented in recent reports by international organizations $[7,8]$. Other documents on youth risk behavior offer data that alert to a diversity of problems, such as peer violence at school, especially during adolescence [9-11].

One of the issues on which the research has focused heavily is the patterns of motivation for substance use [12,13]. Many of the beliefs that adolescents have about the consequences of using 
substances such as alcohol or tobacco are erroneous [14], which is associated with minimizing derived risks [15]. Thus, adolescents with positive attitudes and/or expectations toward the use of alcohol show a higher risk in starting and maintaining use behavior [16-18]. In this line, several studies have associated impulsivity and sensation-seeking with drug use [17,19,20]. Malmberg et al. [21] suggest that impulsivity exerts a fundamental role in maintaining the use of alcohol and tobacco during early adolescence. These relationships could be particularly apparent during adolescence when changes in development occur and, at the same time, more opportunities for substance use appear [22,23]. A study by Pérez-Fuentes et al. [24] analyzing the relationship between impulsivity and the use of alcohol and tobacco by adolescents contained data suggesting that students who say they are users score significantly higher on metrics of impulsivity. Charles et al. [25] found that higher levels of impulsivity and sensation-seeking become more evident in early adolescence and are predictors of higher substance use in mid-adolescence.

Impulsivity is also present as a characteristic trait in aggressors and is a factor predisposing to involvement in violence [26]. Furthermore, in combination with sensation-seeking behavioral patterns, it has been shown that both work as predictors of different types of aggression $[27,28]$. In addition to individual factors [29-31], adopting certain risk behaviors is also subject to other determinant factors in the construction of self-concept [32,33] and personal wellbeing [34], whether related to family members or peer groups $[35,36]$.

In working on preventing the use of alcohol and other drugs, it is important to consider the theoretical basis for adolescent decision-making about such substances. Litt and Lewis [37] applied the model for decision-making in health by Gerrard, Gibbons, Houlihan, Stock, and Pomery [38] to adolescent alcohol use and found that the adolescent alcohol user employs a largely socially-conditioned decision-making process characterized by very little planning. Recent results [39] have shown that the more they use tobacco and alcohol, the stronger their perception of social support from the peer group and less from the family. Data also derived from this study support the relationship of such use with both reactive and proactive aggression.

Precisely because of the relationship that the literature establishes between substance use and violence [40-42], the development of new lines of research oriented toward preventive intervention for both problems is considered necessary [43]. Both, as social problems derived from risk behaviors in the adolescent population, require intervention directed at developing prosocial behavior while reducing risk behavior. One of the results expected from this type of intervention is responsibility in substance use, in which improvement in the decision-making process intervenes. An effective approach to involvement in episodes of violence also requires the adolescent to acquire awareness of the consequences. At this point, impulsivity has a determining role in the type and intensity of the response, during which it is desirable for the adolescent to become more responsible.

Durkheim's sociology of education [44] refers to the existence of a set of common beliefs (collective conscience) enabling the development of collective action, which commits the individual to acting according to established social norms. In line with this position, the educational context is presented as a scenario where necessary educational action is put into practice to cope with social problems, such as preventing violence or substances use [45]. Therefore, in any of the phenomena analyzed in this article, adequate decision-making is required [46] to promote the sustainable development of responsibility and personal resources in adolescents. This approach to the aforementioned social phenomena enables a social balance to be maintained and sustainable life styles to be developed [47].

The purpose of this study was to identify adolescent profiles according to their use of tobacco/alcohol and violent behavioral patterns, as well as to analyze the extent to which they show impulsivity traits. The following research hypotheses were formulated: (1) It is possible to identify different adolescent profiles by their tobacco/alcohol use and violent behavior repertoires, (2) there is an association between tobacco and alcohol use and violence, and (3) impulsivity is involved in adopting the risk behaviors analyzed, and users and those who score higher in aggressiveness are the most impulsive. 
In brief, an attempt was made to acquire information on the individual characteristics and particularities of a population, which often shares common educational scenarios and problems, enabling a basis to be set for their later analysis from a social perspective.

\section{Materials and Methods}

\subsection{Participants}

The participants were selected by cluster random sampling. A total of 8 high schools were selected at random following the geographic distribution of the city of Almeria. There were 822 high school students in the sample, aged 13 to 18 years, with a mean age of $14.84(S D=0.87)$. Of the whole sample, $51.8 \%(n=426)$ were men and $48.2 \%(n=396)$ were women with mean ages of $14.85(S D=0.87)$ and 14.82 years $(D T=0.86)$, respectively. The distribution of the sample by grade was as follows: $43.7 \%$ were students in their third year ESO $(n=359)$, and the remaining $56.3 \%$ were in their fourth year ESO $(n=463)$.

\subsection{Instruments}

Sociodemographic data on the sample (age, sex, grade) were collected using an ad hoc questionnaire, and information on use of tobacco and alcohol by two items with a dichotomous answer format (yes/no).

Aggression Questionnaire ( $A Q$ ) by Buss and Perry [48]. In this study, the Spanish adaptation of the study by Andreu, Peña, and Graña was applied [49]. The questionnaire consists of 29 items and attempts to evaluate aggressiveness by means of four factors: physical aggressiveness, verbal aggressiveness, hostility, and anger. The 29 items are scored on a 5-point Likert-type scale, where 1 = completely false for me; 2 = rather false for me; 3 = neither true nor false for me; 4 = quite true for me; 5 = completely true for me. The reliability coefficients found in the original study by Buss and Perry varied from 0.72 to 0.85 . For the Spanish adaptation, the authors showed a Cronbach's alpha for the complete scale of 0.88 , while for the scales that comprise it, the coefficients varied from 0.68 to 0.86 . In this study, the Cronbach's alpha was 0.87 for the complete questionnaire, and for each of the scales, it was $\alpha=0.79$ for physical aggression, $\alpha=0.69$ for verbal aggression, $\alpha=0.69$ for anger, and $\alpha=0.68$ for hostility.

State Impulsivity Scale (SIS) by Iribarren, Jiménez-Giménez, García-de Cecilia, and Rubio-Valladolid [50]. This scale is designed to evaluate impulsive behavior defined as a state, that is, impulsivity as a behavioral manifestation that may vary in the short term. It consists of 20 items distributed in 3 subscales: gratification (evaluating the urgency in satisfying impulses, the preference for immediate reward, intolerance of frustration, and the tendency to act without caring about possible negative consequences), automatism (refers to behaviors expressed rigidly and repetitively, without attention to contextual variables), and attentional (evaluates the presence of unplanned behavior, which takes place because of acting too soon and without considering all the available information). Subjects are asked to evaluate the frequency with which each statement is true for them and answer on a 4-point Likert scale. The authors [50] found high reliability, both for the complete scale $(\alpha=0.88)$ and for each of its dimensions: gratification $(\alpha=0.84)$, automatism $(\alpha=0.80)$, and attentional $(\alpha=0.75)$. In our study, alpha was 0.73 (gratification), 0.76 (automatism), and 0.80 (attentional), coinciding with Iribarren et al. [50], with an $\alpha=0.88$ for the total scale.

\subsection{Procedure}

First, the principal of each school was informed of the objectives, procedure, and use of the research data. The pertinent permissions were requested on an informed consent sheet addressed to the parents/guardians, and before the tests were implemented, only students who had paternal authorization were permitted to participate. The participants were provided with instructions for filling out this documentation, as well as guaranteeing their privacy in the data processing. The study 
was approved by the Bioethics Committee at the University of Almeria (Spain). Then, two members of the research group went to the high school to give the tests. The database was built up and analyzed with SPSS v.22.

\subsection{Data Analysis}

First, a 2-stage cluster analysis was done to form the groups of adolescents based on their tobacco and alcohol use variables with a dichotomous (yes/no) response and the continuous quantitative variables related to violence (physical aggression, verbal aggression, anger, and hostility).

After the groups or clusters had been identified, a MANOVA was performed to find any significant differences between the groups with respect to the dependent variables (gratification, automatism, and attentional). To determine the means, which were significantly different, the Scheffé post hoc method for comparisons was applied.

\section{Results}

A cluster analysis with the following variables was done to form the groups: use of tobacco, use of alcohol, physical aggression, verbal aggression, anger, and hostility. A total of three groups of adolescents resulted from these six variables (Figure 1) with the following distribution: $31.8 \%(n=261)$ in Cluster 1, 29.8\% $(n=245)$ in Cluster 2, and the remaining 38.4\% $(n=316)$ in Cluster 3.

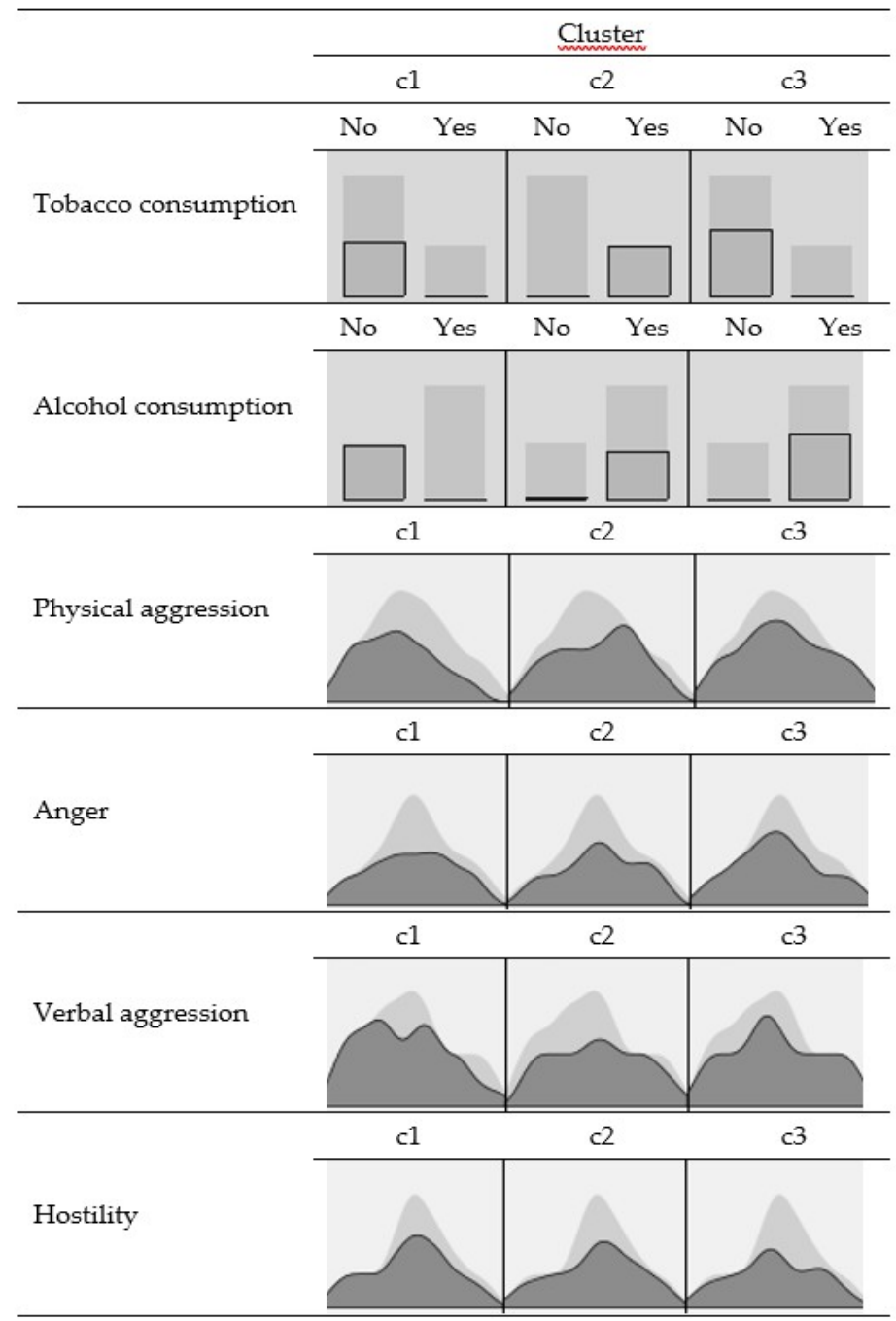

Figure 1. Cluster composition. The variables are presented according to input importance (predictor). 
The first group resulting from the cluster analysis (Cluster 1) was characterized by $100 \%$ of the adolescents not using either tobacco or alcohol and scoring below the mean for the total sample with respect to the violence variables, specifically physical aggression $(M=2.19)$, verbal aggression $(M=2.46)$, anger $(M=2.63)$, and hostility $(M=2.81)$, whereas for the total sample $(N=822)$ the scores were physical aggression $(M=2.47)$, verbal aggression $(M=2.68)$, anger $(M=2.91)$, and hostility $(M=2.93)$.

The second group (Cluster 2), included adolescents who were tobacco (100\%) and alcohol users $(95.1 \%)$ with scores on the violence variables over the mean for the total sample with the following scores: physical aggression $(M=2.79)$, verbal aggression $(M=2.83)$, anger $(M=3.16)$, and hostility $(M=3.04)$.

The third group (Cluster 3) included adolescents who do not smoke (100\%) but who drink alcohol $(100 \%)$. Their mean scores on the violence variables were close to those of the total sample: physical aggression $(M=2.45)$, verbal aggression $(M=2.74)$, anger $(M=2.94)$, and hostility $(M=2.96)$.

The Table 1 shows a summary of the frequency (use of tobacco and alcohol) and mean scores (physical aggression, verbal aggression, anger, and hostility) of the variables analyzed for both the total sample and by cluster.

Table 1. Frequency/mean scores for the total sample and by cluster.

\begin{tabular}{lcccc}
\hline & Total Sample & \multicolumn{3}{c}{ Cluster } \\
\cline { 3 - 5 }$(\boldsymbol{N}=\mathbf{8 2 2})$ & $\begin{array}{c}\mathbf{1} \text { (Cluster 1) } \\
(\boldsymbol{n}=\mathbf{2 6 1})\end{array}$ & $\begin{array}{c}\mathbf{2} \text { (Cluster 2) } \\
(\boldsymbol{n}=\mathbf{2 4 5})\end{array}$ & $\begin{array}{c}\text { 3 (Cluster 3) } \\
(\boldsymbol{n}=\mathbf{3 1 6})\end{array}$ \\
\hline Use of tobacco & Yes 29.8\% & No 100\% & Yes 100\% & No 100\% \\
\hline No 70.2\% & Yes 66.8\% & No 100\% & Yes 95.1\% & Yes 100\% \\
\hline Nof alcohol & $M=2.47$ & $M=2.19$ & $M=2.79$ & $M=2.45$ \\
\hline Verbal aggression & $M=2.68$ & $M=2.46$ & $M=2.83$ & $M=2.74$ \\
\hline Anger & $M=2.91$ & $M=2.63$ & $M=3.16$ & $M=2.94$ \\
\hline Hostility & $M=2.93$ & $M=2.81$ & $M=3.04$ & $M=2.96$ \\
\hline
\end{tabular}

After group classification based on the three-cluster solution, a MANOVA was done to determine whether there were any differences between the clusters in the impulsivity-dependent variables (gratification, automatism, and attentional).

The homogeneity of covariance was examined using the Box's $M$ test, and the null hypothesis of the data fit was rejected $\left(M_{B o x}=25.54 ; F=2.11 ; p<0.05\right)$. The multivariate comparison demonstrated the existence of significant between-group differences (Wilks Lambda $=0.907 ; F_{(6,822)}=13.592 ; p<0.001$; $\left.\eta_{\mathrm{p}}{ }^{2}=0.048\right)$

The Levene test [gratification: $F_{(2,819)}=2.379 ; p=0.093$; automatism: $F_{(2,819)}=2.552 ; p=0.079$; attentional: $F_{(2,819)}=1.735 ; p=0.177$ ] showed that the groups were homogeneous (the null hypothesis of the equality of variance was accepted), so ANOVAs were performed without applying any type of correction, and the Scheffé method was used for post hoc comparison.

The individual analysis of each of the dependent variables (impulsivity dimensions) showed that the relationship was statistically significant in all cases (Table 2). 
Table 2. Means and standard deviations of the groups (clusters) and eta squared $\left(\eta^{2}\right)$ for each of the dependent variables.

\begin{tabular}{lccccccc}
\hline & \multicolumn{2}{c}{ Cluster 1 } & \multicolumn{2}{c}{ Cluster 2 } & \multicolumn{2}{c}{ Cluster 3 } & \multirow{2}{*}{$\boldsymbol{\eta}^{2}$} \\
\cline { 2 - 6 } & $\boldsymbol{M}$ & $\boldsymbol{D T}$ & $\boldsymbol{M}$ & $\boldsymbol{D T}$ & $\boldsymbol{M}$ & $\boldsymbol{D T}$ & \\
\hline Gratification & 11.67 & 0.24 & 14.77 & 0.25 & 13.19 & 0.22 & 0.088 \\
\hline Automatism & 10.82 & 0.23 & 12.79 & 0.24 & 11.99 & 0.21 & 0.039 \\
\hline Attentional & 12.90 & 0.26 & 15.34 & 0.27 & 14.21 & 0.23 & 0.049 \\
\hline
\end{tabular}

With respect to gratification, there were significant differences between the three groups $\left(F_{(2,819)}=39.754 ; p<0.001 ; \eta_{\mathrm{p}}^{2}=0.088\right)$. Post hoc comparisons show that Cluster 2 (tobacco and alcohol users with violence scores over the mean of the total sample) had a significantly higher score $(M=14.77)$ than the rest of the groups. Furthermore, Cluster $3(M=13.19)$ had a significantly higher score than Cluster $1(M=11.67)$.

Significant differences were also found between the groups with respect to automatism $\left(F_{(2,819)}=16.824 ; p<0.001 ; \eta_{\mathrm{p}}^{2}=0.039\right)$. The results of the post hoc comparisons show that both Cluster $2(M=12.79)$ and Cluster $3(M=11.99)$ scored significantly higher than Cluster $1(M=10.82)$.

Finally, with respect to the attentional impulsivity factor, there were also significant between-group differences $\left(F_{(2,819)}=20.907 ; p<0.001 ; \eta_{\mathrm{p}}^{2}=0.049\right)$. Post hoc comparisons show that Cluster 2 had a significantly higher score $(M=15.34)$ than the rest of the groups. The Cluster $3(M=14.21)$ score was in turn significantly higher than that of Cluster $1(M=12.90)$.

\section{Discussion}

Based on the results, three groups or profiles were identified from the combination of tobacco and/or alcohol use and the scores on violent behavioral patterns: (1) Adolescents who do not use alcohol or tobacco and have lower scores on violence than the mean of the total sample, (2) adolescents who use alcohol and tobacco, with violence scores above the mean, and (3) adolescents who use alcohol but not tobacco and have violence scores similar to the mean. In this distribution, it may be observed how the subjects grouped by their affirmative answers on the use of either of the two substances coincide with the cluster where the subjects have the highest scores on the different types of aggression and vice versa. Thus, the relationship found between violence and the use of accessible substances, such as alcohol and tobacco, is in line with recent reports on the topic [7,8]. Moreover, except for the consensus of studies, which support an association between both problems in one way or another [39-41], the results are also in agreement on the influence (as a predictor) of impulsivity on risk behaviors, whether during early [21] or mid-adolescence [25].

Thus, there is no doubt about the presence of certain variables related to impulsivity and sensation-seeking during adolescent decision-making about substance use $[17,19,20]$ or their expression of aggression $[26,28,39]$. In this study, statistically significant differences were found between the profiles identified for all the impulsivity factors, where the group of adolescents who used alcohol and tobacco and had the highest aggression scores were also the most impulsive. It must also be considered that drinking alcohol is characterized by little reflection and planning in decision-making $[17,37]$.

These practical implications should be considered with caution in view of the limitations derived from errors associated with the measurement method. In this case, there could be certain sources of error such as malingering [51] and/or denying consumption [52]. However, there is no doubt that any case is related to the honesty of the responses of the adolescents in the sample.

\section{Conclusions}

An analysis of factors possibly associated with an adolescent's risk behavior makes possible and orients intervention in different stages of development. In other words, from a public healthcare standpoint, we attempted to identify those factors that place adolescent health and wellbeing, in its 
widest sense, at risk through a combined approach to both problems [43]. Therefore, having these data will enable preventive programs to be designed for implementation, not only adequately, but also at the right time for them to be most effective. From this approach, considering the variability of factors that intervene in both problems [29,31-36], these data should be considered in future lines of research. Programs must also be designed to promote successful adolescent decision-making for the sustainable development of responsibility, the acquisition of individual resources, and the prevalence of prosocial competencies over involvement in substance use and risk behavior.

Furthermore, the sociology of education proposes priorities for action, such as the following: (1) achieving consequent articulation between education and strategies for the social development of a community and its current problems, and (2) promoting participation of social sectors in approaching these problems. Thus, our interest is in providing a more integrated approach to the analysis of the social problems posed (sociology), to which efforts can be directed at designing and implementing future educational action (education).

In this framework, society demands that education, as a social phenomenon, generate changes and constitute a factor in positive adolescent development, in all its areas (personal, psychological, social, family, etc.). The social function of education can therefore promote values, attitudes, and behavioral patterns adaptive to a social reality in constant change. From this viewpoint, and based on the matters analyzed in this study, new discussions emerge on the relationships between sociology, education, and in this case, adolescent development.

Author Contributions: M.d.C.P.-F., M.d.M.M.J., A.B.B.M., and J.J.G.L. contributed to the conception and design of the review. J.J.G.L. applied the search strategy. All the authors applied the selection criteria. All the authors completed the assessment of risk of bias. All the authors analyzed and interpreted data. M.d.M.M.J., M.d.C.P.-F., and A.B.B.M. wrote the manuscript. M.d.M.M.J., M.d.C.P.-F., and J.J.G.L. edited the manuscript. M.d.C.P.-F. is responsible for the overall project.

Funding: This research received no external funding.

Acknowledgments: The present study was undertaken in collaboration with the Excma. Diputación Provincial de Almería. Part of this work has been developed thanks to the financing of the University of Almería, which contributed to the hiring of research personnel in predoctoral training, which was granted to Ana Belén Barragán Martín.

Conflicts of Interest: The authors declare no conflict of interest.

\section{References}

1. Otis, K.L.; Huebner, E.S.; Hills, K.J. Origins of Early Adolescents' Hope: Personality, Parental Attachment, and Stressful Life Events. Can. J. Sch. Psychol. 2016, 31, 102-121. [CrossRef]

2. Bermúdez, M.P.; Teva, I.; Buela-Casal, G. Influencia de variables sociodemográficas sobre los estilos de afrontamiento, el estrés social y la búsqueda de sensaciones sexuales en adolescentes [Influence of sociodemographic variables on coping styles, social stress, and sexual sensation seeking in Adolescent]. Psicothema 2009, 21, 220-226.

3. Espada, J.P.; Gonzálvez, M.T.; Orgilés, M.; Lloret, D.; Guillén-Riquelme, A. Meta-analysis of the Effectiveness of School Substance Abuse Prevention Programs in Spain. Psicothema 2015, 27, 5-12. [CrossRef]

4. Oliva, A.; Parra, A.; Sánchez-Queija, I. Consumo de sustancias durante la adolescencia: Trayectorias evolutivas y consecuencias para el ajuste psicológico [Consumption of substances during adolescence: Evolutionary trajectories and consequences for psychological adjustment]. Int. J. Clin. Health Psychol. 2008, 8, 153-169.

5. Ministerio de Sanidad, Servicios Sociales e Igualdad. Encuesta Sobre Uso de Drogas en Estudiantes de Enseñanzas Secundarias (ESTUDES) 2014/2015 [Survey on Drug Use in Secondary Education Students (ESTUDES) 2014/2015]; Ministerio de Sanidad, Servicios Sociales e Igualdad: Madrid, España, 2016.

6. Ministerio de Sanidad, Servicios Sociales e Igualdad. Encuesta Sobre Alcohol y Drogas en España (EDADES) 2017/2018 [Survey on Alcohol and Drugs in Spain (EDADES) 2017/2018]; Ministerio de Sanidad, Consumo y Bienestar Social: Madrid, España, 2018. 
7. Bushman, B.J.; Newman, K.; Calvert, S.L.; Downey, G.; Dredze, M.; Gottfredson, M.; Jablonski, N.G.; Masten, A.S.; Morrill, C.; Neill, D.B.; et al. Youth violence: What we know and what we need to know. Am. Psychol. 2016, 71, 17. [CrossRef] [PubMed]

8. World Health Organization. Health for the World's Adolescents. A Second Chance in the Second Decade; World Health Organization: Ginebra, Switzerland, 2014.

9. Calmaestra, J.; Escorial, A.; García, P.; del Moral, C.; Perazzo, C.; Ubrich, T. Yo a Eso no Juego: Bullying y Ciberbullying en la Infancia [I Do Not Play That: Bullying and Cyberbullying in Childhood]; Save the Children: Madrid, España, 2016.

10. Estévez, E.; Jiménez, T.I.; Moreno, D. Aggressive behavior in adolescence as a predictor of personal, family, and school adjustment problems. Psicothema 2018, 30, 66-73. [CrossRef] [PubMed]

11. Nieto, B.; Portela, I.; López, E.; Domínguez, V. Violencia verbal en el alumnado de Educación Secundaria Obligatoria [Verbal violence in the students of Compulsory Secondary Education]. Eur. J. Investig. Health Psychol. 2018, 8, 5-14. [CrossRef]

12. Marín-Navarrete, R.; Horigian, V.E.; Medina-Mora, M.E.; Verdeja, R.E.; Alonso, E.; Feaster, D.J.; Fernández-Mondragón, J.; Berlanga, C.; Sánchez-Huesca, R.; Lima-Rodríguez, C.; et al. Intervención de incremento motivacional en centros ambulatorios para las adicciones: Un ensayo aleatorizado multi-céntrico [Motivational enhancement treatment in outpatient addiction centers: A multisite randomized trial]. Int. J. Clin. Health Psychol. 2017, 17, 9-19. [CrossRef]

13. Serafini, K.; Shipley, L.; Stewart, D.G. Motivation and substance use outcomes among adolescents in a school-based intervention. Addict. Behav. 2016, 53, 74-79. [CrossRef]

14. Hincapié, C.; Corredor, S.; Barbosa, C.; Méndez, M.; Muñoz, L. Evaluación de un producto sonoro en las creencias referidas al consumo de alcohol en jóvenes universitarios [Evaluation of a sound product in beliefs related to alcohol consumption in university students]. Horizontes Pedagógicos 2013, 15, 83-95.

15. Suárez, C.; Del Moral, G.; Martínez, B.; John, B.; Musitu, G. El patrón de consumo de alcohol en adultos desde la perspectiva de los adolescentes [Adult pattern of alcohol use as perceived by adolescents]. Gac. Sanit. 2016, 30, 11-17. [CrossRef] [PubMed]

16. Almeida, L.; Pérez-Fuentes, M.C.; Casanova, J.R.; Gázquez, J.J.; Molero, M.M. Alcohol expectancy-adolescent questionnaire (AEQ-AB): Validation for Portuguese college students. Health Addict. 2018, 18, 155-163. [CrossRef]

17. Gázquez, J.J.; Pérez-Fuentes, M.C.; Molero, M.M.; Martos, A.; Cardila, F.; Barragán, A.B.; Carrión, J.J.; Garzón, A.; Mercader, I. Adaptación española del Cuestionario de Expectativas del Alcohol en adolescentes [Spanish adaptation of the Alcohol Expectancy-Adolescent Questionnaire, Brief]. Eur. J. Investig. Health Psychol. 2015, 5, 357-369. [CrossRef]

18. Pérez-Fuentes, M.C.; Molero, M.M.; Gázquez, J.J. Expectations and Sensation-Seeking as predictors of Binge Drinking in adolescents. Ann. Psicol. 2019, 35, 124-130. [CrossRef]

19. Leeman, R.F.; Hoff, R.A.; Krishnan-Sarin, S.; Patock-Peckhan, J.A.; Potenza, M.N. Impulsivity, Sensation-Seeking, and Part-Time Job Status in Relation to Substance Use and Gambling in Adolescents. J. Adolesc. Health 2014, 54, 460-466. [CrossRef] [PubMed]

20. Neumann, A.; Barker, E.; Koot, H.; Maughan, B. The Role of Contextual Risk, Impulsivity, and Parental Knowledge in the Development of Adolescent Antisocial Behavior. J. Abnorm. Psychol. 2010, 119, 534-545. [CrossRef] [PubMed]

21. Malmberg, M.; Kleinjan, M.; Overbeek, G.; Vermulst, A.A.; Lammers, J.; Engels, R. Are There Reciprocal Relationships between Substance Use Risk Personality Profiles and Alcohol or Tobacco Use in Early Adolescence? Addict. Behav. 2013, 38, 2851-2859. [CrossRef]

22. Alcázar, M.A.; Verdejo, A.; Bouso, J.C.; Ortega, J. Búsqueda de sensaciones y conducta antisocial [Sensation seeking and antisocial behaviour]. Anuario de Psicología Jurídica 2015, 25, 75-80. [CrossRef]

23. Alarcón, P.A.; Pérez-Luco, R.X.; Wenger, L.S.; Salvo, S.I.; Chesta, S.A. Personality and offense severity in adolescents with persistent antisocial behavior. Revista Iberoamericana de Psicología y Salud 2018, 9, 58-74. [CrossRef]

24. Pérez-Fuentes, M.C.; Gázquez, J.J.; Molero, M.M.; Cardila, F.; Martos, A.; Barragán, A.B.; Garzón, A.; Carrión, J.J.; Mercader, I. Impulsividad y consumo de alcohol y tabaco en adolescentes [Adolescent impulsiveness and use of alcohol and tobacco]. Eur. J. Investig. Health Psychol. Educ. 2015, 5, 371-382. [CrossRef] 
25. Charles, N.E.; Ryan, S.R.; Bray, B.C.; Mathias, C.W.; Acheson, A.; Dougherty, D.M. Altered Developmental Trajectories for Impulsivity and Sensation Seeking among Adolescent Substance Users. Addict. Behav. 2016, 60, 235-241. [CrossRef]

26. Pichardo, M.C.; Arco, J.L.; Fernández-Martín, F.D. La relación entre la impulsividad cognitiva (R-I) y el maltrato entre iguales o "bullying" en educación primaria [The relationship between cognitive impulsivity (R-I) and peer abuse or "bullying" in primary education]. Anál. Modif. Conducta 2005, 31, 359-377.

27. Gázquez, J.J.; Pérez-Fuentes, M.C.; Molero, M.M.; Simón, M.M. Búsqueda de sensaciones e impulsividad como predictores de la agresión en adolescentes [Sensation seeking and impulsivity as predictors of aggression in adolescents]. Psychol. Soc. Educ. 2016, 8, 243-255.

28. Pérez-Fuentes, M.C.; Molero, M.M.; Carrión, J.J.; Mercader, I.; Gázquez, J.J. Sensation-Seeking and Impulsivity as Predictors of Reactive and Proactive Aggression in Adolescents. Front. Psychol. 2016, 7, 1447. [CrossRef] [PubMed]

29. Gázquez, J.J.; Pérez-Fuentes, M.C.; Carrión, J.J.; Luque, A.; Molero, M.M. Interpersonal Value Profiles and Analysis to Adolescent Behavior and Social Attitudes. Rev. Psicodidact. 2015, 20, 321-337. [CrossRef]

30. Guo, S. A meta-analysis of the predictors of cyberbullying perpetration and victimization. Psychol. Sch. 2016, 53, 432-453. [CrossRef]

31. Molero, M.M.; Pérez-Fuentes, M.C.; Luque, A.; Martos, A.; Barragán, A.B.; Simón, M.M. Interpersonal Values and Academic Performance Related to Delinquent Behaviors. Front. Psychol. 2016, 7, 1480. [CrossRef]

32. Álvaro, J.I.; Zurita, F.; Castro, M.; Martínez, A.; García, S. Relación entre consumo de tabaco y alcohol y el autoconcepto en adolescentes españoles [The relationship between consumption of tobacco and alcohol and self-concept in Spanish adolescents]. Rev. Complut. Educ. 2016, 27, 533-550.

33. Morales, F.M. Relaciones entre afrontamiento del estrés cotidiano, autoconcepto, habilidades sociales e inteligencia emocional [Relationships between coping with daily stress, self-concept, social skills and emotional intelligence]. Eur. J. Educ. Psychol. 2017, 10, 41-48. [CrossRef]

34. Goñi, E.; Esnaola, I.; Rodríguez, A.; Camino, I. Personal self-concept and satisfaction with life in adolescence, youth and adulthood. Psicothema 2015, 27, 52-58. [CrossRef]

35. Cutrín, O.; Gómez-Fraguela, J.A.; Maneiro, L.; Sobral, J. Effects of parenting practices through deviant peers on nonviolent and violent antisocial behaviours in middle- and late-adolescence. Eur. J. Psychol. Appl. Legal Context 2017, 9, 75-82. [CrossRef]

36. Rodríguez-Fernández, A.; Ramos-Díaz, E.; Madariaga, J.M.; Arrivillaga, A.; Galende, N. Steps in the construction and verification of an explanatory model of psychosocial adjustment. Eur. J. Educ. Psychol. 2016, 9, 20-28. [CrossRef]

37. Litt, D.M.; Lewis, M.A. Examining a social reaction model in the prediction of adolescent alcohol use. Addict. Behav. 2016, 60, 160-164. [CrossRef] [PubMed]

38. Gerrard, M.; Gibbons, F.X.; Houlihan, A.E.; Stock, M.L.; Pomery, E.A. A Dual-Process approach to health risk decision making: The prototype willingness model. Dev. Rev. 2008, 28, 29-61. [CrossRef]

39. Gázquez, J.J.; Pérez-Fuentes, M.C.; Molero, M.M.; Barragán, A.B.; Martos, A.; Sánchez-Marchán, C. Drug use in adolescents in relation to social support and reactive and proactive aggressive behavior. Psicothema 2016, 28, 318-322. [CrossRef] [PubMed]

40. David-Ferdon, C.; Simon, T.R. Preventing Youth Violence: Opportunities for Action; National Center for Injury Prevention and Control, Centers for Disease Control and Prevention: Atlanta, GA, USA, 2014.

41. Green, K.M.; Doherty, E.E.; Zebrak, K.A.; Ensminger, M.E. Association Between Adolescent Drinking and Adult Violence: Evidence from a Longitudinal Study of Urban African Americans. J. Stud. Alcohol. Drugs 2011, 72, 701-710. [CrossRef] [PubMed]

42. Maldonado-Molina, M.M.; Reingle, J.M.; Jennings, W.G. Does alcohol use predict violent behaviors? The relationship between alcohol use and violence in a nationally representative longitudinal sample. Youth Violence Juv. Justice 2011, 9, 99-111. [CrossRef]

43. Gómez-Acosta, C.A.; Londoño, C. Modelo predictor del consumo responsable de alcohol y el comportamiento típicamente no violento en adolescentes [Predictive model of responsible consumption of alcohol and Typically not violent behavior in adolescents]. Health Addict. 2013, 13, 23-33. [CrossRef]

44. Durkheim, E. La División del Trabajo Social; Planeta-Agostini: Barcelona, España, 1985.

45. Crosnoe, R. The Connection between Academic Failure and Adolescent Drinking in Secondary School. Sociol. Educ. 2016, 79, 44-60. [CrossRef] 
46. Rosenqvist, E. Two Functions of Peer Influence on Upper-secondary Education Application Behavior. Sociol. Educ. 2018, 91, 72-89. [CrossRef]

47. United Nations. Transforming Our World: The 2030 Agenda for Sustainable Development. Available online: https://sustainabledevelopment.un.org/content/documents/21252030\%20Agenda\% 20for\%20Sustainable\%20Development\%20web.pdf (accessed on 18 January 2019).

48. Buss, A.H.; Perry, M. The Aggression Questionnaire. J. Personal. Soc. Psychol. 1992, 63, 452-459. [CrossRef]

49. Andreu, J.M.; Peña, M.E.; Graña, J.L. Adaptación psicométrica de la versión española del Cuestionario de Agresión [Psychometric adaptation of the Spanish version of the Aggression Questionnaire]. Psicothema 2002, 14, 476-482.

50. Iribarren, M.M.; Jiménez-Giménez, M.; García-de Cecilia, J.M.; Rubio-Valladolid, G. Validación y Propiedades psicométricas de la escala de impulsividad estado (EIE) [Validation and Psychometric Properties of the State Impulsivity Scale (EIE)]. Actas Españolas de Psiquiatría 2011, 39, 49-60. [PubMed]

51. Arce, R.; Fariña, F.; Vilariño, M. Daño psicológico en casos de víctimas de violencia de género: Un estudio comparativo de las evaluaciones forenses [Psychological injury in intimate partner violence cases: A contrastive analysis of forensic measures]. Revista Iberoamericana de Psicología y Salud 2015, 6, 72-80. [CrossRef]

52. Fariña, F.; Redondo, L.; Seijo, D.; Novo, M.; Arce, R. A meta-analytic review of the MMPI validity scales and indexes to detect defensiveness in custody evaluations. Int. J. Clin. Health Psychol. 2017, 17, 128-138. [CrossRef] [PubMed]

(C) 2019 by the authors. Licensee MDPI, Basel, Switzerland. This article is an open access article distributed under the terms and conditions of the Creative Commons Attribution (CC BY) license (http:/ / creativecommons.org/licenses/by/4.0/). 